\title{
ASSESSMENT OF FULL-TIME DENTAL HYGIENE FACULTY PARTICIPATION IN CLINICAL PRACTICE
}

\author{
Jessica Reneé Kiser, RDH, BS
}

A thesis submitted to the faculty of the University of North Carolina at Chapel Hill in partial fulfillment of the requirements for the degree of Master of Science in Dental Hygiene Education in the Department of Dental Ecology, School of Dentistry.

Chapel Hill

2006

Approved by

Advisor: Rebecca S. Wilder, RDH, MS Reader: Deborah E. Fleming, RDH, MS

Reader: Mary C. George, RDH, M.Ed 


\begin{abstract}
JESSICA R. KISER: Assessment of Full-time Dental Hygiene Faculty Participation in Clinical Practice (Under the direction of Rebecca S. Wilder)

The purpose of the research project was to determine the number of United States (U.S.) dental hygiene (DH) programs having full-time (FT) faculty members who provide direct patient care. A pilot-tested questionnaire was placed on Survey Monkey, a survey website. Two-hundred and seventy-eight U.S. DH program directors received two E-mails requesting their participation. A response rate of $69.1 \%$ was achieved and showed that $14.2 \%$ of the programs required FT faculty members to provide direct patient care while $67.0 \%$ of the programs had faculty members who participated. The majority (95.4\%) of directors indicated maintaining clinical skills and current clinical techniques as advantages of faculty participation in direct patient care, while $48 \%$ of directors indicated participation takes time away from being an educator. Overall, the majority of DH programs did not require FT faculty members to participate in direct patient care; however, over half of the programs had faculty members who participated.
\end{abstract}




\section{ACKNOWLEDGEMENTS}

I would like to thank my thesis committee, Rebecca Wilder, Mary George, and Deborah Fleming, for their guidance, encouragement, and dedication to this research project. I would also like to thank my family and friends for their support. A special thanks to Dr. Ceib Phillips and Michael Pannucci for their assistance in the statistical analysis of the data.

I would also like to thank my fellow graduate student, Mariola Luciano, for her friendship and guidance throughout this research project. 
TABLE OF CONTENTS

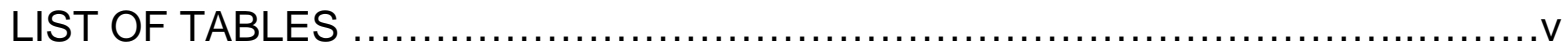

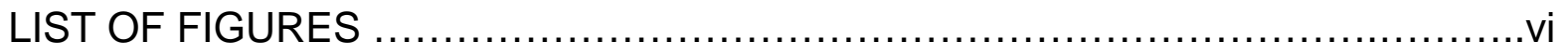

LIST OF ABBREVIATIONS ......................................................

Chapter

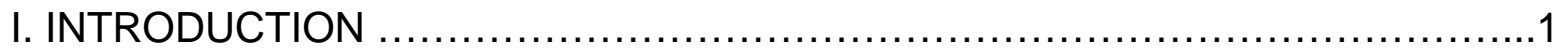

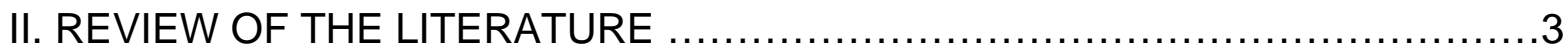

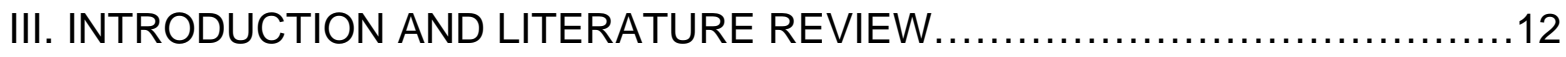

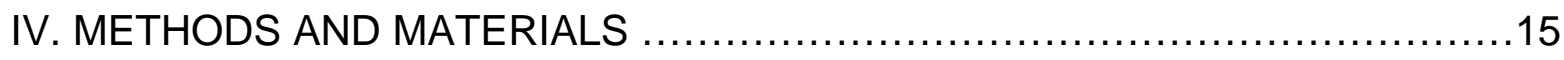

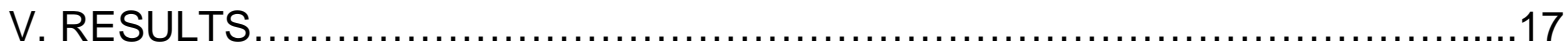

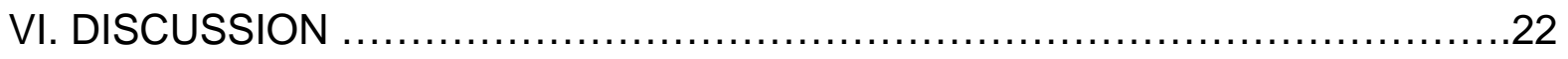

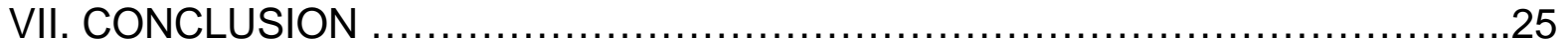

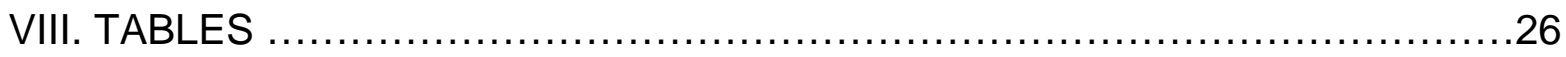

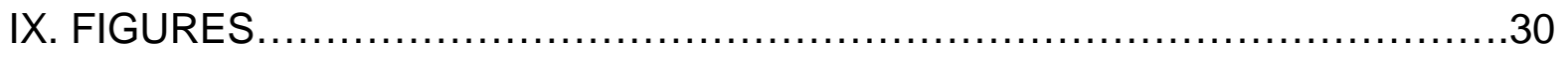

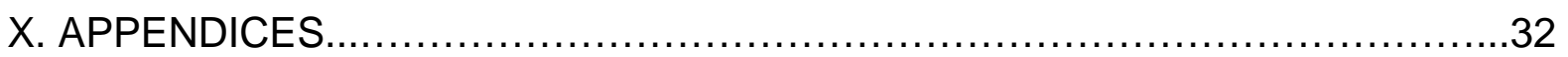

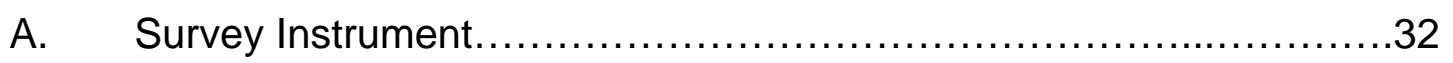

B. Sample of Program Directors' Responses to Open-ended Question............................................................

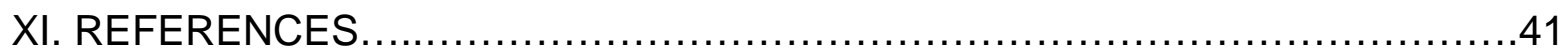




\section{LIST OF TABLES}

Table 1 Advantages and Disadvantages to participating in Direct Patient Care Indicated by Responding DH Program Directors.........................26

Table 2 Attitudes of DH Directors Regarding Direct Patient Care by DH Full-time

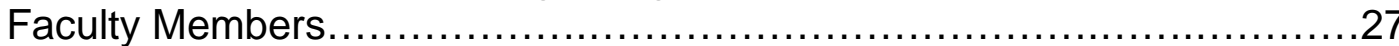

Table 3 Comparison of DH Programs Requirement of Direct Patient Care and Beliefs of Faculty Participation in Direct Patient Care ........................28

Table 4 Comparison of DH Programs Participation in Direct Patient Care and Beliefs of Faculty Participation in Direct Patient Care 


\section{LIST OF FIGURES}

Figure 1 Institutional Setting Demographics of Respondents........................30

Figure 2 Professional Environment Faculty Members Participate in

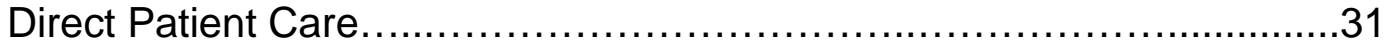




\section{LIST OF ABBREVIATIONS}

$\begin{array}{ll}\text { AAMC } & \text { Association of American Medical Colleges } \\ \text { ADA } & \text { American Dental Association } \\ \text { ADN } & \text { Associate Degree Nursing } \\ \text { DH } & \text { Dental Hygiene } \\ \text { FPP } & \text { Faculty Practice Plan } \\ \text { FT } & \text { Full-time } \\ \text { IRB } & \text { Institutional Review Board } \\ \text { NLN } & \text { National League of Nursing } \\ \text { OT } & \text { Occupational Therapy } \\ \text { URL } & \text { Uniform Resource Locator } \\ \text { U.S. } & \text { United States }\end{array}$




\section{CHAPTER I}

\section{INTRODUCTION}

In professional health care programs students are taught skills in a clinical setting along with didactic instruction. Dental hygiene $(\mathrm{DH})$ students learn to become health care professionals through didactic and clinical courses. Accredited DH programs are those programs receiving approval from the Commission on Dental Accreditation by the American Dental Association (ADA). ${ }^{1}$ The Accreditation Standards for Dental Hygiene Education Programs ensure that students graduating from programs at different institutions receive the same level of formal education. The Accreditation Standards consist of six sections that must be completed by the $\mathrm{DH}$ program to receive accreditation. One standard deals with administration, faculty members, and staff, which states "opportunities must be provided for full-time faculty to continue their professional development," which can be accomplished "through clinical/practice experience." ${ }^{11}$

Dental hygiene programs hire faculty members based on clinical and academic experience. Once individuals become full-time (FT) faculty members they are immersed in the academic world. Some academic institutions expect faculty members to keep abreast of clinical skills through clinical practice. Studies have been conducted on faculty practice plans (FPP) in health care professions, including dental schools, which only assessed dental faculty members. ${ }^{2-10}$ However, the 
research is lacking on opportunities for $\mathrm{DH}$ faculties to practice in a clinical setting as health care providers. The purpose of this research project was to determine the number of DH programs with FT faculty members participating in direct patient care as part of or in addition to their academic responsibilities. 


\section{CHAPTER II}

\section{REVIEW OF THE LITERATURE}

\section{Significance}

The Commission on Dental Accreditation of the American Dental Association (ADA) developed the Accreditation Standards for Dental Hygiene (DH) Education Programs. The Accreditation Standards state "opportunities must be provided for full-time faculty to continue their professional development," which can be accomplished "through activities such as professional association involvement, research, publishing and clinical/practice experience." The Accreditation Standards also state "faculty members must have current knowledge of the specific subjects they are teaching and background in appropriate educational methodology." The intent of this statement means "faculty should have background in education theory and practice, current concepts relative to the specific subjects they are teaching, and current clinical practice experience." ${ }^{11}$ What is currently not known is the extent to which DH faculties are participating in clinical practice outside of their academic responsibilities in order to stay current with their skills. Therefore, the purpose of this study was to survey DH program directors regarding the involvement of their FT faculty members in direct patient care, not including clinical supervision of students.

\section{Faculty Practice Plans in Professional Programs}

A few studies have been conducted on dental FPP in the United States (U.S.) and

Canada. $^{2-5}$ However; the studies did not include DH programs. In 1972 Gordon 
mailed a survey to fifty-one dental schools in the U.S. to determine if they had intramural dental practices. Forty-one surveys were returned with seventeen schools (41.5\%) reporting they had an intramural practice. The schools with an intramural practice and those planning to establish one soon completed the remainder of the survey, a total of twenty-two schools; however, not all responded to each question. Thirteen schools (81.3\%) said that the intramural dental practice helped faculties maintain "clinical proficiency," eleven schools (68.8\%) said the intramural dental practice assisted in teaching students, and eighteen schools (100\%) agreed the time put in was worth the additional salary. ${ }^{2}$ Ten schools (71.4\%) also indicated that working in the intramural dental practice provided the "opportunity for clinical reaserach."

Also in 1972, Speed et al. surveyed fifty-two U.S. dental schools to determine if faculties were allowed to "operate private dental practices during" the academic year. Forty-seven schools returned the survey with thirty-seven schools $(78.7 \%)$ responding that FT faculties were allowed to operate private dental practices. Nineteen (51.4\%) of the thirty-seven schools allowing private practice operation provided a setting for intramural practices. ${ }^{3}$

In 1993 Shnorhokian and Zullo mailed surveys to fifty-eight dental schools in the U.S. and ten dental schools in Canada to determine the number of schools with FPP. Fifty-two dental schools (90\%) in the U.S. returned the surveys, indicating thirty-five schools (67\%) had FPP. Eight (80\%) Canadian dental schools returned the surveys and indicated that four (50\%) had FPP. ${ }^{4}$ Out of the twenty-one dental schools that did not have a FPP, eight (38.1\%) indicted there was no setting 
available, six (28.6\%) indicated there was no interest among faculties, and one (5\%) indicated participating in a FPP "dilutes teaching effectiveness." Of the thirty-nine schools with FPP seven schools (17.9\%) required participation among FT faculties and twelve schools (30.8\%) allowed those involved in the FPP to practice at an external setting. Thirty-two schools responded to the salary portion of the survey and twenty-five schools (78.1\%) indicated faculties were paid in addition to their base salary. ${ }^{4}$

Almog et al. surveyed fifty-three U.S. dental schools in 1996 to determine if the schools had FPP. Forty-two schools responded and thirty-six (85.7\%) indicated they had a FPP. Telephone calls were utilized to determine if the non-responding schools had FPP, with nine indicating they had FPP. ${ }^{5}$ A setting was available in the dental school for the FPP in more than $90 \%$ of the responding dental schools and $69.4 \%$ of responding schools indicated there was an off-site clinic associated with the institution. ${ }^{5}$

Numerous studies have been conducted on U.S. FPP in nursing programs. In 1979 Bellinger and Sanders surveyed 287 National League of Nursing (NLN) accredited baccalaureate programs and achieved a $41 \%$ response rate $(n=118)$. Thirty-five (30\%) programs had a FPP and eighty-two (70\%) programs had no plan. Eight of the programs with no policy indicated that faculties did practice but did not provide specific information and three programs indicated that faculties could practice on weekends or during summer breaks. ${ }^{6}$

In 1985 Barger mailed a survey to 427 NLN accredited baccalaureate programs to determine if nursing centers, a site associated with the institution, were provided to 
faculties to practice. Three hundred and thirty-one schools responded and fifty-one schools had nursing centers. Almost $18 \%$ of schools with nursing centers required faculties to practice while $8.9 \%$ without nursing centers required faculties to practice. $^{7,8}$ The schools with a tenure track system incorporated faculty practice into their decision in $41 \%$ of the schools with a nursing center and $28.7 \%$ schools without a nursing center. Faculty practice is considered in promotion decisions in $44.2 \%$ of the schools with a nursing center and $37.9 \%$ of schools without nursing centers. ${ }^{7,8}$

In 1995 Scoggin et al. mailed a questionnaire to department chairs and faculty members of the eighty-eight Occupational Therapy (OT) programs in the U.S. to determine involvement of faculties in clinical practice. ${ }^{9}$ Participants included thirtynine program department chairs and 162 faculty members. Twenty-three (60\%) programs had FPP and forty-four (32.4\%) faculty members indicated that during the past year they were involved in clinical practice. Faculty members indicated that they were involved in clinical practice to keep current with clinical techniques (59\%), to develop contacts and network (27\%), and to supplement their income (2\%). ${ }^{9}$ Fifty-nine percent of faculty members indicated that clinical practice takes time away from being an educator and is difficult to schedule; however, $39 \%$ indicated that clinical practice does not interfere with teaching responsibilities. ${ }^{9}$

In 1989 Bentley et al. surveyed 125 schools who were members of the Association of American Medical Colleges (AAMC) regarding medical FPP and achieved a $59.2 \%(n=74)$ response rate. ${ }^{10}$ Ninety-six percent of responding colleges required medical faculty members to participate in the FPP. Sixty-two percent of responding colleges indicated the FPP was within the medical school, while 38\% 
were not associated with the institution. Income from the FPP was used for supplementing faculty members' salaries, medical school funding, and clinical operations of the practice. The majority of responding schools indicated a payment was provided to the medical school (95\%), and $58 \%$ of respondents indicated a percentage of income was placed into department accounts. ${ }^{10}$

\section{Defining Faculty Practice}

Several definitions of faculty practice emerge from the literature. McClure defines faculty practice as "doing what you teach others to do." ${ }^{11}$ Millonig defines faculty practice "as an activity that is related to the care of patients," which "is scholarly in nature." Millonig further explains that faculty practice does not include clinical teaching "because it has as its primary goal the education of the student."12 Algase defines faculty practice as "advancement of the discipline of nursing." ${ }^{\text {13 }}$ WakefieldFisher defines faculty practice as an expansion of teaching, which incorporates clinical practice. ${ }^{14}$ Collison and Parsons have two definitions for faculty practice. The first definition is a broad one, which includes the treatment of a patient by a faculty member during student clinics. The second definition is more restricted in which faculty members are the only provider of treatment to patients. ${ }^{15}$ Kuhn's definition of faculty practice does not entail teaching and supervising students in clinic. ${ }^{16}$ Kramer et al. defines faculty practice as providing "service or care to patients/clients as their central focus" and does not include does not include supervision or clinical teaching "because the central focus is education of the student." ${ }^{17}$ 


\section{Barriers and Benefits to Faculty Practice}

Numerous barriers to faculty practice have been cited in the literature including reimbursement issues and available space of intramural practices. ${ }^{4,6,11,12,18-23}$ Faculty practice can be seen as taking time away from the role of educating the students. ${ }^{18-20}$ Some feel that faculties who get involved with in direct patient care may decide to leave the school as an educator and work only in private practice. ${ }^{19}$ Finding time to practice along with faculties' responsibilities has also been cited as a barrier to faculty practice. ${ }^{6,13,21}$ Others have reported that faculty practice can get in the way of promotion and tenure by not allowing the faculty members enough time to fully complete scholarly activities. ${ }^{11,23}$

Several benefits to faculty practice have been cited in the literature such as the possibility of additional income and to enhance a portfolio for tenure and promotion. ${ }^{15,18,19,24}$ Maintaining clinical skills and enriching the classroom environment are seen as advantages to faculty practice..$^{6,7,12,17-19,21,24,25}$ Faculty members involved in practice can try new theories and develop research ideas. ${ }^{6,7,12,15,17,21,25}$ Faculty members who practice have increased credibility with students and can role model clinical situations. ${ }^{12,15,17,23}$ Millonig states the greatest reward for faculty practice "is involvement in the quality of care provided to the patients." ${ }^{12}$ Others have reported that the faculty member gains professional development and personal satisfaction from clinical practice..$^{12,15}$

\section{Faculty Practice and Teaching}

In 1982, Cameron et al. wrote on mandatory requirements for clinical practice of dental and DH faculty members. The article stated "clinical experience is an 
important asset for educators involved in teaching dental skills." Clinical practice provides faculty members with the opportunity to keep current with skills they teach students. ${ }^{18}$ The article further explains that faculty members involved in clinical practice can use their experience in the classroom. ${ }^{18}$ In 1983 Anderson et al. surveyed 573 nurse educators involved in clinical practice. One of the questions asked the reason for considering faculty practice. The top three responses to the question were "enriching their teaching, maintaining clinical skills, and personal satisfaction." 24

Myers conducted a survey in 1977 to determine what dental faculty members and dental students identified as important characteristics of an effective clinical instructor. Responses were obtained from eighty-eight faculty members and ninetynine students at the College of Dentistry at The Ohio State University. Ranked second out of seventy-eight items was the clinical instructor should be "at least as competent with regard to dental knowledge and skill as he expects his students to be." ${ }^{26}$ Ranked sixteenth out of seventy-eight items was the clinical instructor should be up to date on clinical procedures. ${ }^{26}$

Hartland et al. examined important characteristics of clinical instructors. A Likertscale questionnaire of twenty-two characteristics of clinical instructors was sent to nurse anesthesia program directors, clinical instructors, and students $(n=482){ }^{27}$ Three hundred and fifty-four (73.4\%) participated in the survey and the most important characteristic identified from the combined participating groups was clinical competence/judgment. ${ }^{27}$ 
Gignac-Caille et al. surveyed associate degree nursing (ADN) students and faculty members from five programs in Michigan to identify characteristics of efficient clinical instructors. A total of 292 students and fifty-nine faculty members were surveyed using questions rated on a Likert-scale. ${ }^{28}$ Students indicated that the most important characteristic of clinical instructors was "demonstrates clinical skill and judgment," while faculty members ranked it eighth. Faculty members indicated the most important characteristic of clinical instructors was that they explained material clearly, which students ranked second. ${ }^{28}$

Johnsen et al. surveyed 348 nurse educators in Norway to determine important nurse educators' characteristics. Norwegian educators identified teaching skills and nursing skills as most important. ${ }^{29}$ In the nursing skills category "high regard for clinical skills" was identified as more important than other items in the category; however, a less important item identified was "practical skills to take part in patient care." Respondents answered open ended questions in which some indicated they valued practical clinical skills, while others did not. Comments also indicated that some saw nursing educators as only teachers and "not practitioners." 29

In 2005 Buchel et al. surveyed 179 medical residents and 117 medical faculty members about the most important and least important teaching attributes. Each selected the top three and bottom three attributes from a list of fifteen items. A response rate of $58 \%$ among residents and $65 \%$ among faculties was achieved. Forty-seven percent of the residents and $62 \%$ of faculties ranked clinical competencies as one of their top important teaching attributes. By combining 
residents and faculties, $53 \%(n=96)$ ranked clinical competency as the most important attribute. ${ }^{30}$ 


\section{CHAPTER III}

\section{INTRODUCTION AND LITERATURE REVIEW}

The Commission on Dental Accreditation of the American Dental Association (ADA) developed the Accreditation Standards for Dental Hygiene (DH) Education Programs. The Accreditation Standards state "opportunities must be provided for full-time faculty to continue their professional development," which can be accomplished "through activities such as professional association involvement, research, publishing and clinical/practice experience." The Accreditation Standards also state "faculty members must have current knowledge of the specific subjects they are teaching and background in appropriate educational methodology." The intent of this statement means "faculty should have background in education theory and practice, current concepts relative to the specific subjects they are teaching, and current clinical practice experience." ${ }^{1}$

A few studies have been conducted on dental FPP in the United States (U.S.) and Canada. $^{2-5}$ However; the studies did not include DH programs. Numerous studies have been conducted on FPP in health care programs, such as nursing, OT, and medicine..$^{6-10}$

Several definitions of faculty practice emerge from the literature. McClure defines faculty practice as "doing what you teach others to do."11 Millonig defines faculty practice "as an activity that is related to the care of patients," which "is scholarly in 
nature." Millonig further explains that faculty practice does not include clinical teaching "because it has as its primary goal the education of the student."12 Algase defines faculty practice as "advancement of the discipline of nursing." ${ }^{13}$ WakefieldFisher defines faculty practice as an expansion of teaching, which incorporates clinical practice. ${ }^{14}$ Collison and Parsons have two definitions for faculty practice. The first definition is a broad one, which includes the treatment of a patient by a faculty member during student clinics. The second definition is more restricted in which faculty members are the only providers of treatment to patients. ${ }^{15}$ Kuhn's definition of faculty practice does not entail teaching and supervising students in clinic. ${ }^{16}$ Kramer et al. defines faculty practice as providing "service or care to patients/clients as their central focus" and does not include supervision or clinical teaching "because the central focus is education of the student." ${ }^{\text {"7 }}$ For the purpose of this research project faculty practice is defined as direct patient care, where the faculty member is the sole provider of treatment, and does not include clinical supervision of students.

Numerous barriers and benefits of faculty practice have been cited in dental and nursing literature. Barriers include available space, reimbursement issues, and time. ${ }^{4,6,12-14,18-23}$ Benefits to faculty practice include maintaining clinical skills, enriching the classroom environment, additional income, and developing research agendas. ${ }^{6-7,12,15,17-19,21,24,25}$

What is currently not known is the extent to which $\mathrm{DH}$ faculties are participating in clinical practice outside of their academic responsibilities in order to stay current with their clinical skills. Therefore, the purpose of this study was to survey $\mathrm{DH}$ program 
directors regarding the involvement of their FT faculty members in direct patient care, not including clinical supervision of students. Questions in this project also assessed attitudes and beliefs of $\mathrm{DH}$ directors regarding clinical practice among faculty members and opportunities for salary supplementation. 


\section{CHAPTER IV}

\section{METHODS AND MATERIALS}

A twenty question survey (Appendix A) was designed and subdivided into four sections: demographics; clinical practice patterns; direct patient care settings; and attitudes and opinions. The survey contained Likert-scale questions along with open and closed ended questions. The survey was reviewed by a survey specialist at the H. W. Odum Institute for Research in Social Science at the University of North Carolina at Chapel Hill. Corrections were made based on feedback.

The research project was submitted and approved by the Institutional Review Board (IRB) at the University of North Carolina at Chapel Hill. The survey was pilot tested by five $\mathrm{DH}$ program directors from different institutional settings. Minor corrections were made and resubmitted to the IRB for approval. Following IRB approval the survey was posted on Survey Monkey, an online survey website engine. Survey Monkey provided a Uniform Resource Locator (URL) for the survey.

A list of accredited U.S. DH programs was obtained from the American Dental Hygienists' Association (ADHA) in July 2005. Program websites along with telephone calls were utilized to locate E-mail addresses for $\mathrm{DH}$ program directors. A total of 278 program directors were identified and served as the study population. Two E-mails with the URL to the survey were sent to each program director three weeks apart requesting their participation in the research study. Participants were 
informed that the survey was anonymous and that there were no incentives to participating.

The data was reported as percentages in Survey Monkey. Bivariate analyses were performed in order to acquire correlations using the Chi-square test when both variables being compared were nominal. The Mantel-Haenszel row mean score test was used when a nominal and ordinal variable were being compared. Data was analyzed by SAS version 9 . 


\section{CHAPTER V}

\section{RESULTS}

A total of 192 program directors responded to the online survey, achieving a response rate of $69.1 \%$. Figure 1 presents the distribution of respondents' institutional setting. For analysis purposes technical/vocational colleges and community/junior colleges were combined. Almost half of the programs $(49.5 \%)$ had one to five faculty members in a nine or ten month position and $67 \%$ of programs had one to five faculty members in a twelve month position.

When asked if the program requires FT faculty members to participate in direct patient care, $14 \%$ of programs indicated they do require participation. Fifty-nine percent of respondents whose program does not require participation in direct patient care indicated that faculty schedules and obligations do not permit time to participate. Thirty-three percent reported that the institution does not allow faculty members to provide direct patient care and that it is not part of faculty contracts.

When asked if the program elects to have FT faculty members participating in direct patient care, $67 \%$ of programs indicated faculties do participate. A majority (72.7\%) of programs with faculties not participating in direct patient care indicated that faculty schedules and obligations do not permit time. Forty-five percent said there was no opportunity for the faculty members to participate and $34.5 \%$ indicated that there is no setting available. Only $16 \%$ of respondents indicated that FT faculty 
members are not interested in providing direct patient care and only $7 \%$ indicated state practice acts limit faculty members from participating.

Figure 2 presents the professional environment in which FT faculty members participate in direct patient care. Of the programs that have FT faculties participating in direct patient care, $60 \%$ indicated faculty members are on a $<12$ month contract and provide direct patient care during nonacademic periods. Twenty percent of programs indicated that a set number of hours are allocated each week to be used at the discretion of the faculty for professional development, which may be used for clinical practice, research, or consulting. Only $11.7 \%$ of respondents indicated that a set number of hours are allocated each week, specifically for clinical practice. Eighty-three percent of respondents reported faculties who participate in clinical practice are financially compensated with the majority of these programs (95.1\%) reporting compensation by an hourly, salary, or commission pay that is not part of the university base salary.

One section of the survey focused on attitudes and opinions with specific questions about advantages and disadvantages of providing direct patient care (Table 1). Maintaining clinical skills and keeping current with clinical techniques were noted as advantages to direct patient care by $95 \%$ of respondents. Enhancing clinical instruction (75.6\%), providing additional income (72\%), and enriching the classroom environment (68.6\%) were the next three most cited advantages. Over half $(53.1 \%)$ of respondents indicated there are no disadvantages to providing direct patient care and $48 \%$ indicated it takes time away from the primary role of being an educator. 
Table 2 presents the results from the Likert-scale questions contained in the attitudes and opinions section of the survey. Seventy-two percent of respondents strongly agreed or agreed that $\mathrm{DH}$ faculties should be given the opportunity to provide direct patient care, while only $35 \%$ strongly agreed or agreed that $\mathrm{DH}$ faculties should be required to participate in direct patient care. Seventy-six percent of respondents strongly agreed or agreed that $\mathrm{DH}$ faculties involved in direct patient care enhance their competency as clinical instructors while 19\% of respondents neither agreed nor disagreed.

Bivariate analyses were performed in order to acquire correlations using the Chisquare test when both variables being compared were nominal. The MantelHaenszel row mean score test was used when a nominal and ordinal variable were being compared. Statistically significant data revealed that respondents from a college / university with a dental school $(28 \%)$ were more likely to require FT faculties to participate in direct patient care $(p$-value $=0.016)$. Only $9.6 \%$ of technical / vocational / community / junior colleges and $23.3 \%$ of college/universities without a dental school require FT faculties to participate in direct patient care. Moreover, compared to two-year college respondents (69.3\%), respondents from a college / university with a dental school (95.5\%) were more likely to agree that faculties should be given the opportunity to provide direct patient care while teaching in $\mathrm{DH}$ education ( $p$-value=0.0069).

Participants from programs requiring FT faculties to provide direct patient care were more in agreement with four of the five Likert-scale questions in the attitudes and opinions section compared to those programs not requiring direct patient care. 
For example, $48.2 \%$ of participants requiring $\mathrm{FT}$ faculties to participate agreed $\mathrm{DH}$ faculties should be required to provide direct patient care while teaching in $\mathrm{DH}$ education (Table 3). Participants from programs with FT faculties participating in direct patient care were more in agreement with three of the five Likert-scale questions in the attitudes and opinions section compared to programs without faculties participating in care. For example, $79.5 \%$ of participants with FT faculties participating agreed $\mathrm{DH}$ faculties should be given the opportunity to provide direct patient care while teaching in $\mathrm{DH}$ education (Table 4). Overall, respondents who required faculties and those with faculties participating in direct patient care were always more in agreement with the Likert-scale questions than other respondents.

Participants from a college / university with a dental school (40\%) were more likely to agree that providing direct patient care takes time away from research opportunities ( $p$-value<0.0001), compared to $8 \%$ from technical / vocational / community / junior colleges and $13.3 \%$ from college / universities without a dental school. Also, participants from programs requiring direct patient care were more likely to agree that direct patient care fulfills partial requirement for promotion or tenure (33.3\%), while those from programs that do not require participation were more likely to disagree $(93.9 \%$, p-value $<0.0001)$. Furthermore, participants from programs requiring faculties to participate in direct patient care were more likely to agree that faculties are respected more by students and faculties for their clinical application of knowledge (85.2\%, p-value=0.0076).

Participants from programs that do not have FT faculties participating in direct patient care were more likely not to choose the following advantages of providing 
care from a list of nine: additional income $(45.2 \%, p$-value $=0.01)$; maintaining clinical skills/keeping current with clinical techniques (19.4\%, p-value=0.0132); and greater respect by students and faculties for their clinical application of knowledge (46.8\%, $\mathrm{p}$-value $=0.0487$. Additionally, participants from programs with FT faculties providing direct patient care were more likely to report that there are no disadvantages to providing care (53.6\%). Respondents from programs without faculties providing direct patient care were more likely to report there are disadvantages to providing care $(62.9 \%, p$-value $=0.0335)$. 


\section{CHAPTER VI \\ DISCUSSION}

This study confirmed that the majority of $\mathrm{DH}$ programs in the U.S. are not requiring participation in direct patient care, but over half of the programs have faculty members participating, either during nonacademic periods or during times the institution sets aside each week to be used at the faculty members' discretion. Only $29 \%$ of programs indicated that faculty members participate in direct patient care at a location associated with the institution. This number is less than reported in the 1996 Almog et al. study where it was found that $96 \%$ of dental schools had FPP associated with the institution. ${ }^{5}$ However, compared with Barger's findings of nursing programs $(15 \%$ of nursing programs had nursing centers for faculty practice), DH programs had a higher percentage of practice locations associated with the institution. ${ }^{7.8}$ It would be interesting to know if $\mathrm{DH}$ faculties would be more encouraged to provide direct patient care if more institutions had a faculty practice. Another question to ask is if a DH faculty practice could be another mechanism to increase income for the institution. In addition, it could be used as a center to provide care for those with little access.

DH program directors also indicated numerous advantages to direct patient care that have been cited before in the literature, such as additional income, ${ }^{12,15,18,19,24}$

opportunity for tenure and promotion, ${ }^{6,7,15}$ maintaining clinical skills, ${ }^{12,17-19,21,24,25}$ and 
enriching the classroom environment. ${ }^{6,12,15,17,18,21,24,25}$ Respondents also indicated numerous disadvantages to direct patient care that have been reported in the literature, such as encouraging individuals to leave the academic world to pursue clinical work and taking time away from the primary role of being an educator. ${ }^{12,18-20}$ Forty-eight percent of respondents indicated participating in direct patient care takes time away from being an educator. This percent is less when compared to Scoggin et al. where it was found that among OT programs $59 \%$ of respondents indicated clinical practice takes time away from the educator role. ${ }^{9}$ Scoggin et al. also found OT faculties (32\%) were participating in clinical practice less than $\mathrm{DH}$ faculties (67\%). Faculty shortages could be a reason for these findings because FT faculties have to increase their workload at programs with faculty shortages.

A limitation to this study is that the questionnaire was completed by $\mathrm{DH}$ program directors and not FT DH faculty members. Therefore, the program directors were reporting what they believe are issues related to direct patient care, and may not necessarily be the opinions of the individual faculty members. Another limitation is not all program directors from accredited $\mathrm{DH}$ programs in the U.S. responded to the questionnaire, possibly due to internet connection problems and time limitations. The E-mails were sent to program directors in August of 2005, the beginning of a new semester and a busy time for them. Other respondents were confused about the definition used in the study to define direct patient care, even though it was defined in the E-mails, and others indicated they did not respond because they did not have any faculty members that participated in direct patient care. 
This study did not assess the number of years of clinical experience among DH faculty members, which may be an indication of why not all faculty members are required or participate in direct patient care while being employed as educators. A future study could assess clinical experience along with participation in clinical practice of FT DH educators.

Overall, the data revealed that over half of the respondents have FT faculty members participating in direct patient care. The data also concluded similar findings that have been published in other articles. This study provides needed information on opportunities for $\mathrm{DH}$ faculties to practice in a clinical setting as health care providers and may present essential data to programs that desire faculty members to participate in direct patient care. 


\section{CHAPTER VII CONCLUSION}

The research found that while the majority of $\mathrm{DH}$ programs participating in the research project do not require $\mathrm{FT}$ faculty members to participate in direct patient care; over half of the programs have FT faculty members who participate in the treatment of patients. The primary professional environment in which faculty members participate in direct patient care is in private dental office, followed by affiliation with a dental team to provide comprehensive care within the institution and health departments / community clinics. Dental hygiene program directors are generally in favor of allowing faculty members the opportunity to practice and think that it enhances their competency as clinical instructors. 
Table 1. Advantages and Disadvantages to participating in Direct Patient Care indicated by Responding DH Program Directors

\begin{tabular}{|c|c|c|c|}
\hline Advantages & Respondents & Disadvantages & Respondents \\
\hline $\begin{array}{l}\text { Maintaining clinical } \\
\text { skills/keeping } \\
\text { current with clinical } \\
\text { technique }\end{array}$ & $95.4 \%$ & $\begin{array}{l}\text { There are no } \\
\text { disadvantages to } \\
\text { providing direct } \\
\text { patient care }\end{array}$ & $53.1 \%$ \\
\hline $\begin{array}{c}\text { Enhanced clinical } \\
\text { instruction }\end{array}$ & $75.6 \%$ & $\begin{array}{l}\text { Taking time away } \\
\text { from the primary } \\
\text { role of being an } \\
\text { educator }\end{array}$ & $48 \%$ \\
\hline Additional income & $72 \%$ & $\begin{array}{l}\text { Taking time away } \\
\text { from research } \\
\text { opportunities }\end{array}$ & $14.9 \%$ \\
\hline $\begin{array}{l}\text { Enriching the } \\
\text { classroom } \\
\text { environment }\end{array}$ & $68.6 \%$ & $\begin{array}{l}\text { May encourage } \\
\text { individuals to leave } \\
\text { the academic world }\end{array}$ & $13.1 \%$ \\
\hline $\begin{array}{l}\text { Respected more by } \\
\text { students \& faculty } \\
\text { for their clinical } \\
\text { application of } \\
\text { knowledge }\end{array}$ & $67.4 \%$ & $\begin{array}{l}\text { Provides little or no } \\
\text { additional financial } \\
\text { incentive for the } \\
\text { time put in }\end{array}$ & $8.6 \%$ \\
\hline $\begin{array}{l}\text { Professional } \\
\text { development }\end{array}$ & $55.4 \%$ & $\begin{array}{l}\text { Private practice } \\
\text { methods are } \\
\text { brought into the } \\
\text { institution and are } \\
\text { different from } \\
\text { institutional } \\
\text { instructions }\end{array}$ & $1.1 \%$ \\
\hline $\begin{array}{l}\text { Development of } \\
\text { research } \\
\text { agendas }\end{array}$ & $12 \%$ & & \\
\hline $\begin{array}{l}\text { Fulfill partial } \\
\text { requirements for } \\
\text { promotion and } \\
\text { tenure }\end{array}$ & $10.9 \%$ & & \\
\hline $\begin{array}{l}\text { Networking/Maintai } \\
\text { ning ties with dental } \\
\text { community }\end{array}$ & $1 \%$ & & \\
\hline $\begin{array}{c}\text { Apply new } \\
\text { materials \& } \\
\text { techniques to } \\
\text { dental hygiene } \\
\text { practice }\end{array}$ & $1 \%$ & & \\
\hline
\end{tabular}


Table 2. Attitudes of DH Directors regarding direct patient care by $\mathrm{DH}$ full-time faculty members

\begin{tabular}{|c|c|c|c|c|}
\hline \multicolumn{5}{|c|}{$\begin{array}{l}\text { Dental hygiene faculty members should be required to provide direct } \\
\text { patient care while teaching in dental hygiene education. }\end{array}$} \\
\hline $\begin{array}{l}11.8 \% \\
\text { Strongly } \\
\text { Agree }\end{array}$ & $\begin{array}{l}23 \% \\
\text { Agree }\end{array}$ & $\begin{array}{l}27.5 \% \\
\text { Neutral }\end{array}$ & $\begin{array}{l}29.2 \% \\
\text { Disagree }\end{array}$ & $\begin{array}{l}8.4 \% \\
\text { Strongly } \\
\text { Disagree }\end{array}$ \\
\hline \multicolumn{5}{|c|}{$\begin{array}{l}\text { Dental hygiene faculty members should be given the opportunity to } \\
\text { provide direct patient care while teaching in dental hygiene } \\
\text { education. }\end{array}$} \\
\hline $\begin{array}{l}30.3 \% \\
\text { Strongly } \\
\text { Agree }\end{array}$ & $\begin{array}{l}42.1 \% \\
\text { Agree }\end{array}$ & $\begin{array}{l}20.8 \% \\
\text { Neutral }\end{array}$ & $\begin{array}{l}6.2 \% \\
\text { Disagree }\end{array}$ & $\begin{array}{l}0.6 \% \\
\text { Strongly } \\
\text { Disagree }\end{array}$ \\
\hline \multicolumn{5}{|c|}{$\begin{array}{l}\text { Dental hygiene faculty members who provide direct patient care } \\
\text { enhance their competency as clinical instructors. }\end{array}$} \\
\hline $\begin{array}{l}33.7 \% \\
\text { Strongly } \\
\text { Agree }\end{array}$ & $\begin{array}{l}42.1 \% \\
\text { Agree }\end{array}$ & $\begin{array}{l}19.1 \% \\
\text { Neutral }\end{array}$ & $\begin{array}{l}4.5 \% \\
\text { Disagree }\end{array}$ & $\begin{array}{l}0.6 \% \\
\text { Strongly } \\
\text { Disagree }\end{array}$ \\
\hline \multicolumn{5}{|c|}{$\begin{array}{c}\text { Dental hygiene clinical instructors should be required to provide direct } \\
\text { patient care. }\end{array}$} \\
\hline $\begin{array}{l}15.7 \% \\
\text { Strongly } \\
\text { Agree }\end{array}$ & $\begin{array}{l}25.3 \% \\
\text { Agree }\end{array}$ & $\begin{array}{l}27 \% \\
\text { Neutral }\end{array}$ & $\begin{array}{l}28.1 \% \\
\text { Disagree }\end{array}$ & $\begin{array}{l}3.9 \% \\
\text { Strongly } \\
\text { Disagree }\end{array}$ \\
\hline
\end{tabular}


Table 3. Comparison of DH Programs Requirement of Direct Patient Care and Beliefs of Faculty Participation in Direct Patient Care

\begin{tabular}{|c|c|c|c|c|}
\hline \multirow{2}{*}{\multicolumn{2}{|c|}{ Likert-scale Question }} & \multicolumn{2}{|c|}{$\begin{array}{c}\text { Require Direct Patient } \\
\text { Care (\%) }\end{array}$} & \multirow[t]{2}{*}{$p$-value } \\
\hline & & Yes & No & \\
\hline \multirow{5}{*}{$\begin{array}{l}\text { DH faculties should be } \\
\text { required to provide } \\
\text { direct patient care } \\
\text { while teaching in } D H \\
\text { education }\end{array}$} & SA & $29.6 \%$ & $8.6 \%$ & \multirow[t]{5}{*}{$0.0102^{*}$} \\
\hline & A & $18.5 \%$ & $23.8 \%$ & \\
\hline & $\mathrm{N}$ & $33.3 \%$ & $26.5 \%$ & \\
\hline & $D$ & $14.8 \%$ & $31.8 \%$ & \\
\hline & SD & $3.7 \%$ & $9.3 \%$ & \\
\hline \multirow{5}{*}{$\begin{array}{l}\text { DH faculties should be } \\
\text { given the opportunity } \\
\text { to provide direct } \\
\text { patient care while } \\
\text { teaching in DH } \\
\text { education }\end{array}$} & SA & $48.2 \%$ & $27.1 \%$ & \multirow[t]{5}{*}{$0.0186^{*}$} \\
\hline & A & $37 \%$ & $43.1 \%$ & \\
\hline & $\mathrm{N}$ & $14.8 \%$ & $21.9 \%$ & \\
\hline & $D$ & $0 \%$ & $7.3 \%$ & \\
\hline & SD & $0 \%$ & $1 \%$ & \\
\hline \multirow{5}{*}{$\begin{array}{l}\text { DH faculties who } \\
\text { provide direct patient } \\
\text { care enhance their } \\
\text { competency as clinical } \\
\text { instructors }\end{array}$} & SA & $66.7 \%$ & $27.8 \%$ & \multirow[t]{5}{*}{$0.009^{*}$} \\
\hline & $A$ & $18.5 \%$ & $46.4 \%$ & \\
\hline & $\mathrm{N}$ & $14.8 \%$ & $19.9 \%$ & \\
\hline & D & $0 \%$ & $5 \%$ & \\
\hline & SD & $0 \%$ & $1 \%$ & \\
\hline \multirow{5}{*}{$\begin{array}{c}\text { DH clinical instructors } \\
\text { should be required to } \\
\text { provide direct patient } \\
\text { care }\end{array}$} & SA & $37 \%$ & $11.9 \%$ & \multirow[t]{5}{*}{0.0036} \\
\hline & A & $25.9 \%$ & $25.2 \%$ & \\
\hline & $\mathrm{N}$ & $18.5 \%$ & $28.5 \%$ & \\
\hline & D & $18.5 \%$ & $29.8 \%$ & \\
\hline & SD & $0 \%$ & $4.6 \%$ & \\
\hline
\end{tabular}

$\mathrm{SA}=$ Strongly Agree; $\mathrm{A}=$ Agree; $\mathrm{N}=$ Neither Agree nor Disagree; $\mathrm{D}=$ Disagree; $\mathrm{SD}=$ Strongly Disagree

*Statistically Significant at the alpha $=0.05$ level 
Table 4. Comparison of DH Programs Participation in Direct Patient Care and Beliefs of Faculty Participation in Direct Patient Care

\begin{tabular}{|c|c|c|c|c|}
\hline \multirow{2}{*}{\multicolumn{2}{|c|}{ Likert-scale Question }} & \multicolumn{2}{|c|}{$\begin{array}{c}\text { Require Direct Patient } \\
\text { Care (\%) }\end{array}$} & \multirow[t]{2}{*}{$p$-value } \\
\hline & & Yes & No & \\
\hline \multirow{5}{*}{$\begin{array}{l}\text { DH faculties should be } \\
\text { required to provide } \\
\text { direct patient care } \\
\text { while teaching in } D H \\
\text { education }\end{array}$} & SA & $14.8 \%$ & $5.4 \%$ & \multirow[t]{5}{*}{0.0523} \\
\hline & A & $24.6 \%$ & $19.6 \%$ & \\
\hline & $N$ & $26.2 \%$ & $30.4 \%$ & \\
\hline & $D$ & $27.1 \%$ & $33.9 \%$ & \\
\hline & SD & $7.4 \%$ & $10.7 \%$ & \\
\hline \multirow{5}{*}{$\begin{array}{c}\text { DH faculties should be } \\
\text { given the opportunity } \\
\text { to provide direct } \\
\text { patient care while } \\
\text { teaching in } D H \\
\text { education }\end{array}$} & SA & $36.9 \%$ & $16.1 \%$ & \multirow[t]{5}{*}{0.0004} \\
\hline & A & $42.6 \%$ & $41.1 \%$ & \\
\hline & $\mathrm{N}$ & $16.4 \%$ & $30.4 \%$ & \\
\hline & D & $3.3 \%$ & $12.5 \%$ & \\
\hline & SD & $1 \%$ & $0 \%$ & \\
\hline \multirow{5}{*}{$\begin{array}{l}\text { DH faculties who } \\
\text { provide direct patient } \\
\text { care enhance their } \\
\text { competency as clinical } \\
\text { instructors }\end{array}$} & SA & $41 \%$ & $17.9 \%$ & \multirow[t]{5}{*}{0.0046} \\
\hline & $A$ & $38.5 \%$ & $50 \%$ & \\
\hline & $\mathrm{N}$ & $15.6 \%$ & $26.8 \%$ & \\
\hline & D & $4.9 \%$ & $3.6 \%$ & \\
\hline & SD & $0 \%$ & $1.8 \%$ & \\
\hline \multirow{5}{*}{$\begin{array}{c}\text { DH clinical instructors } \\
\text { should be required to } \\
\text { provide direct patient } \\
\text { care }\end{array}$} & SA & $19.7 \%$ & $7.1 \%$ & \multirow[t]{5}{*}{0.0098} \\
\hline & $A$ & $27.1 \%$ & $21.4 \%$ & \\
\hline & $\mathrm{N}$ & $25.4 \%$ & $30.4 \%$ & \\
\hline & D & $25.4 \%$ & $33.9 \%$ & \\
\hline & $\mathrm{SD}$ & $2.5 \%$ & $7.1 \%$ & \\
\hline
\end{tabular}

$\mathrm{SA}=$ Strongly Agree; $\mathrm{A}=$ Agree; $\mathrm{N}=$ Neither Agree nor Disagree; $\mathrm{D}=$ Disagree; $\mathrm{SD}=$ Strongly Disagree

*Statistically Significant at the alpha $=0.05$ level 
Figure 1. Institutional Setting Demographics of Respondents

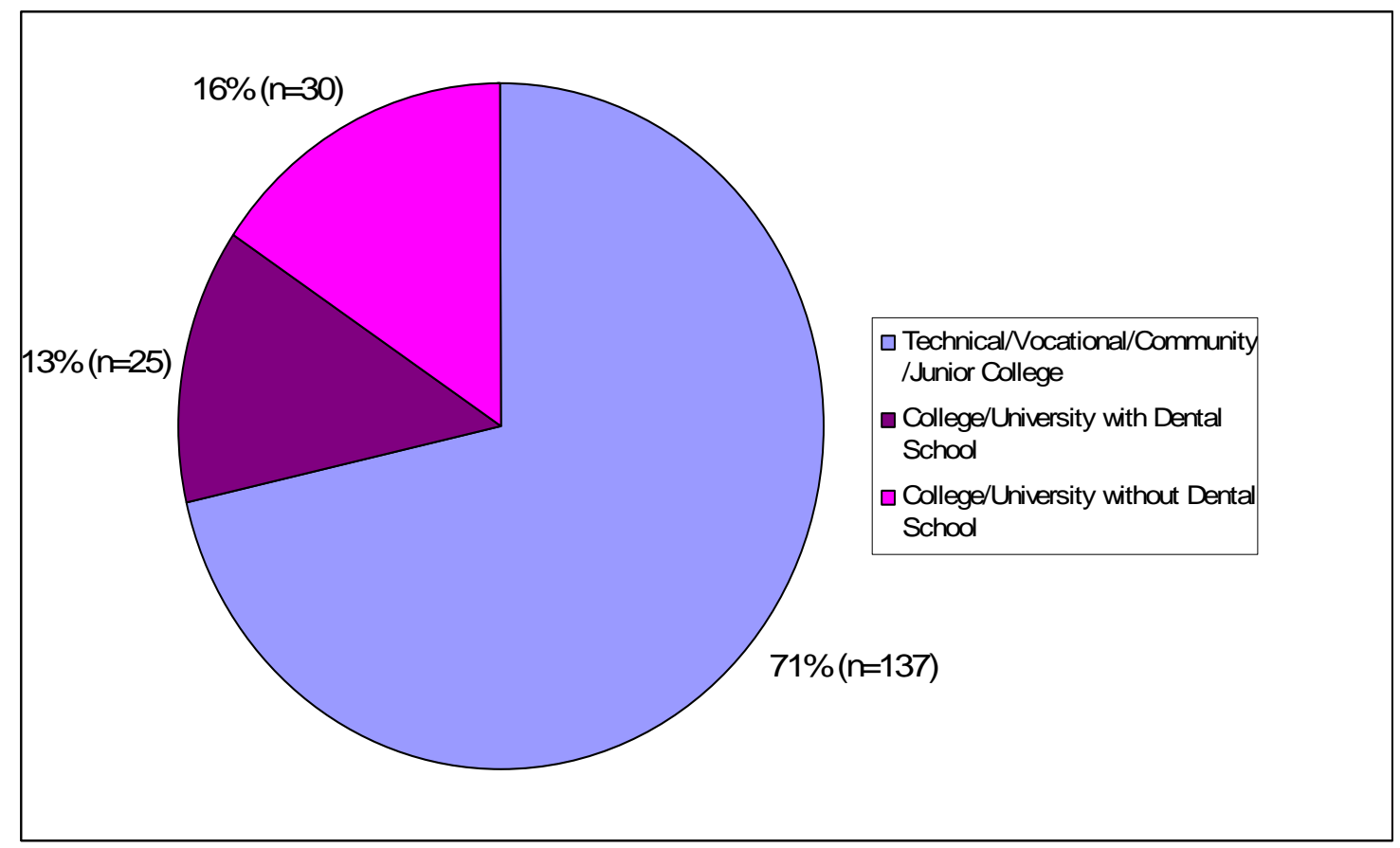


Figure 2. Professional Environment Faculty Members Participate in Direct Patient Care

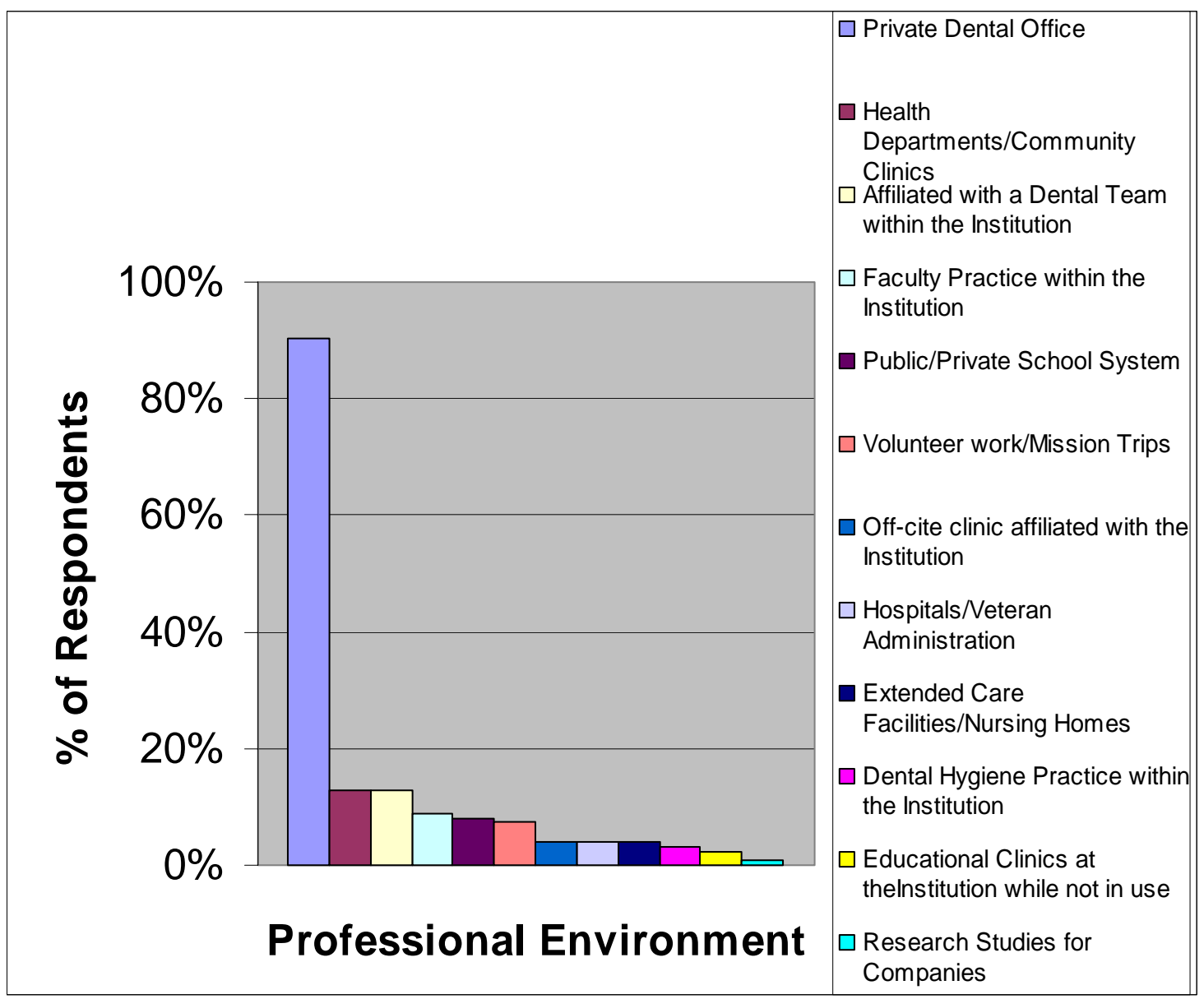




\section{APPENDIX A}

Survey Instrument

\section{Assessment of Full-time Dental Hygiene Faculty Participation In Direct Patient Care}

Instructions: Please complete the questionnaire below within two weeks. Answer questions according to dental hygiene faculty members' involvement in direct patient care, which does not include clinical teaching and clinical supervision.

\section{Demographics}

1. Please indicate the institutional setting of your dental hygiene program.

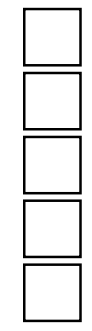

Technical/Vocational Institute 1

Community/Junior College 2

College/University with a Dental $\mathrm{School}_{3}$

College/University without a Dental $\mathrm{School}_{4}$

Other (Specify) 5

2. Please indicate the number of full-time faculty members in your dental hygiene program.

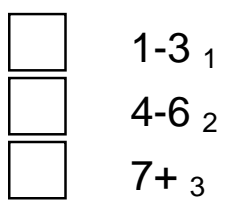

3. Please provide the following information for full-time dental hygiene faculty members.

\# of faculty in 9 or 10 month positions

\# of faculty in 12 month positions 


\section{Clinical Practice Patterns}

4. Does your program require dental hygiene faculty members to provide direct patient care?

\begin{tabular}{|l}
$\square$ \\
Yes \\
\hline$\square$
\end{tabular}

5. If answered no to question \#4 please answer.

Why are dental hygiene faculty members not required to provide direct patient care? Check all that apply.

The institution does not allow faculty members to provide direct patient care

Faculty schedules and obligations do not permit time to provide direct patient care

Faculty members are not interested in providing direct patient care

A setting is not available to provide direct patient care

There is no opportunity for the faculty members to provide direct patient care

$\square$

State practice acts limitations

Other (Specify)

6. Do any of the dental hygiene faculty members at your program provide direct patient care?

Yes

No 
7. If answered no to question \#6 please answer.

Why don't dental hygiene faculty members provide direct patient care? Check all that apply.

The institution does not allow faculty members to provide direct patient care

Faculty schedules and obligations do not permit time to provide direct patient care

Faculty members are not interested in providing direct patient care

A setting is not available to provide direct patient care

There is no opportunity for the faculty members to provide direct patient care

State practice acts limitations

Other (Specify)

\section{Skip to question \#13 if answered question \#7}

8. Please indicate how dental hygiene faculty members are allocated time to provide direct patient care. Check all that apply.

A set number of hours are allocated each week for clinical practice

A set number of hours are allocated each week to be used at faculty discretion for professional development (i.e. clinical practice, research, consulting, etc.)

Faculty members are on a less than 12 month contract and provide direct patient care during nonacademic periods

$\square$ Other (Specify)

9. For those faculty members who provide direct patient care, on average how many hours per week do they devote to this activity.

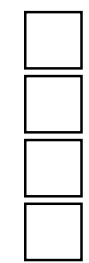

1-4 hours

5-8 hours

9-12 hours

$13+$ hours 


\section{Direct Patient Care Settings}

10. Please indicate all the settings in which your faculty members provide direct patient care. Check all that apply.

$\square$ Affiliated with a dental team, including dentists, to provide comprehensive care within the institution

$\square$ A unit in the faculty practice (i.e. on a referral basis) within the institution

A dental hygiene practice where only dental hygiene procedures are performed within the institution

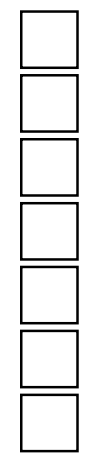
An off-site clinic affiliated with the institution A private dental office Health Departments Hospitals/Veteran Administration (VA) Public/Private school systems Extended care facilities/nursing homes Other (Specify)

11. Are the faculty members financially compensated for the care they provide?<smiles>[Mg][Mg][Mg]</smiles>

12. If answered yes to question $\mathbf{1 1}$ how are faculty members financially compensated? Check all that apply.

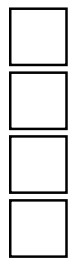

$\square$

Hourly/Salary/Commission (not part of university base salary) As a portion of their university base salary Salary Supplement

Placed in a compensation fund to be used for professional development

Other (Specify) 


\section{Attitudes and Opinions}

13. What do you believe to be some of the advantages to providing direct patient care while being a dental hygiene educator? Check all that apply.

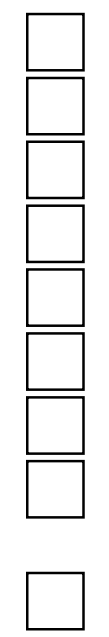

Additional income

Fulfill partial requirements for promotion and tenure

Maintaining clinical skills/keeping current with clinical techniques

Enhanced clinical instruction

Enriching the classroom environment

Development of research agendas

Professional development

Respected more by students and faculty members for their clinical application of knowledge

Other (Specify)

14. What do you believe to be some of the disadvantages to providing direct patient care while being a dental hygiene educator? Check all that apply.

$\square$ Provides little or no additional financial incentive for the time it takes

Taking time away from the primary role of being an educator

Taking away time from research opportunities

May encourage individuals to leave the academic world and work in private practice

There are no disadvantages to providing direct patient care

Other (Specify)

How much do you agree or disagree with the following statements (\#15-\#18):

15. Dental hygiene faculty members should be required to provide direct patient care while teaching in dental hygiene education.

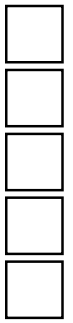

Strongly Agree

Agree

Neither Agree nor Disagree

Disagree

Strongly Disagree 
16. Dental hygiene faculty members should be given the opportunity to provide direct patient care while teaching in dental hygiene education.

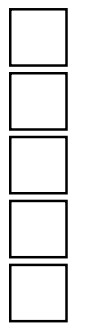

Strongly Agree

Agree

Neither Agree nor Disagree

Disagree

Strongly Disagree

17. Dental hygiene faculty members who provide direct patient care enhance their competency as clinical instructors.

Strongly Agree

Agree

Neither Agree nor Disagree

Disagree

Strongly Disagree

18. Dental hygiene clinical instructors should be required to provide direct patient care.

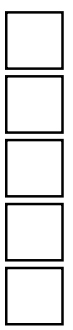

Strongly Agree

Agree

Neither Agree nor Disagree

Disagree

Strongly Disagree

19. For dental hygiene faculty members who are involved in direct patient care what do you consider their overall level of satisfaction.

Very Satisfied

Satisfied

Neither Satisfied nor Dissatisfied

Dissatisfied

Very Dissatisfied

Not Applicable/Faculty members are not involved in direct patient care 
20. We would appreciate any additional information you would like to share regarding dental hygiene faculty involvement in direct patient care.

Thank you for your time in completing the survey!!! 


\section{APPENDIX B}

\section{Sample of DH Program Directors' Open Responses}

- This has been one of my concerns since I started teaching. I know from experience that if you are not practicing clinical dental hygiene, you will lose the strength in your hands and fingers and you can not be as effective when demonstrating calculus removal to students. Our program doesn't REQUIRE it but, as Director, I STRONGLY encourage it.

- Our former dean instituted this requirement many years ago. While it was very difficult initially for those $\mathrm{DH}$ educators who were not in private practice, it has been an incredible asset to the DH program. Students, dental colleagues, and the community highly regard our faculty as a result of this requirement.

- I believe that working during the summer months may be helpful to some clinical instructors; however, I do not feel that this should be a requirement unless the direct patient care is provided within the terms of the contract with the school. Most clinical instructors are providing direct patient care in the student clinics. I have not seen a difference in the instructional abilities between those currently working in practice and those with previous experience.

- Our experience shows it enhances the knowledge provided to the students. It also helps keep skills at a high level. Faculty members are in touch with the attitudes and accepted practices in the private sector. This can give students realistic expectations of the current career paths and opportunities. 
- It gets the faculty out into the dental care field in the community and they are more visible.

- One reason for faculty dissatisfaction with our faculty practice requirement is financial remuneration. We are paid less than what our recent graduates are being paid in external private practices.

- The faculty we hire must be calibrated with one another to effectively evaluate students in the clinical situation. Providing patient care outside of the school has shown us that hygienists tend to pick up bad habits (posture, instrumentation, etc) which are hard to correct for the purpose of education in the clinic.

- I wish that our institution allowed us to be involved in direct patient care. I was not aware when I was hired, that my dean would forbid me from doing such. I was shocked when I was told that I could not use my $1 / 2$ day off to do direct patient care. I was told that if the college found out that I was working in an office during my $1 / 2$ day off, the college would dock my pay. I feel it is a disservice to the students that I cannot keep up with my clinical skill and knowledge by working with patients while I am an instructor. 


\section{CHAPTER XI}

\section{REFERENCES}

1. American Dental Association. Accreditation Standards for Dental Hygiene Education Programs. Chicago: ADA, 1998; 28-9.

2. Gordon J. Intramural Dental Practices in Dental Schools. J Dent Educ 1972; 36(5):24-6.

3. Speed EM, et al. A Survey of Intramural Dental Practices in United States Dental Schools. J Dent Educ 1973; 37(1):26-9.

4. Shnorhokian $\mathrm{HI}$ and Zullo TG. A Survey of Faculty Practice Plans in United States and Canadian Dental Schools. J Dent Educ 1993; 57(4):318-20.

5. Almog DM, Handelman SL, Black PM, and Van Dyke TE. A Survey of Faculty Practices in U.S. Dental Schools. NY State Dent J 1996; 62(10):25-9.

6. Bellinger K and Sanders DH. Faculty Practice Policy. J Nurs Educ 1985; 24(5):214-216.

7. Barger SE. Personnel Issues in Academic Nurse-Managed Centers: The Pitfalls and the Potential. Nurs Educator 1986; 11(3):29-33.

8. Barger SE. Academic Nursing Centers: A Demographic Profile. J Prof Nurs 1986; 2(4):246-51.

9. Scoggin AE, Gibson RW, and Hanson C. Perspectives on Faculty Clinical Practice: Views of Occupational Therapy Curriculum Chairpersons and Faculty Members. Am J Occu Therapy 2000; 54(5):533-40.

10. Bentley JD, et al. Faculty Practice Plans: The Organization and Characteristics of Academic Medical Practice. Acad Med 1991; 66(8):433-39.

11. McClure ML. Faculty Practice: New Definitions, New Opportunities. Nurs Outlook 1987; 35(4):162-66.

12. Millonig VL. Faculty Practice: A View of Its Development, Current Benefits, and Barriers. J Prof Nurs 1986; 2(3):166-72.

13. Algase DL. Faculty Practice: A Means to Advance the Discipline of Nursing. J Nurs Educ 1986; 25(2):74-6.

14. Wakefield-Fisher M. The Issue: Faculty Practice. J Nurs Educ 1983; 22(5):207-10. 
15. Collison CR and Parsons MA. Is Practice a Viable Faculty Role? Nurs Outlook 1980; 28:677-79.

16. Kuhn J. An experience with a joint appointment. Am J Nurs 1982; 82:15701571.

17. Kramer M, Polifroni EC, and Organek N. Effects of Faculty Practice in Student Learning Outcomes. J Prof Nurs 1986; 2(5):289-301.

18. Cameron CA, Brattebo Yamagata, PA and Olswang SG. Mandatory Clinical Practice for Dental and Dental Hygiene Faculty. J Dent Educ 1982; 46(3):153-57.

19. Klooster J. Faculty Practice: Advantages and Disadvantages. J Dent Educ 1978; 42(10):576-78.

20. Van Stewart A. Attitudes Towards Intramural-Practice Programs in American Dental Schools. J Dent Educ 1975; 39(10):687-90.

21. Lambert CE and Lambert VA. Faculty Practice: Unifier of Nursing Education and Nursing Service? J Prof Nurs 1988; 4(5):345-55.

22. Smith GR. Compensating Faculty for Their Clinical Practice. Nurs Outlook 1980; 28(11):673-76.

23. Mauksch IG. Faculty Practice: A Professional Imperative. Nurs Educ 1980; 5(3):21-4.

24. Anderson ER and Pierson P. An Exploratory Study of Faculty Practice: Views of Those Faculty Engaged in Practice Who Teach in an NLN-Accredited Baccalaureate Program. West J Nurs Res 1983; 5(2):129-143.

25. Barger SE. Academic nurse-managed centers: issues of implementation. Fam Comm Health 1986; 9:12-22.

26. Myers B. Beliefs of Dental Faculty and Students about Effective Clinical Teaching Behaviors. J Dent Educ 1977; 41(2):68-76.

27. Hartland W and Londoner CA. Perceived importance of clinical teaching characteristics for nurse anesthesia clinical faculty. J Am Assoc Nurse Anesth 1997; 65(6):547-51.

28. Gignac-Caille AM and Oermann MH. Student and Faculty Perceptions of Effective Clinical Instructors in ADN Programs. J Nurs Educ 2001; 40(8):34753. 
29. Johnsen KO, et al. Nurse Educator Competence: A Study of Norwegian Nurse Educators' Opinions of the Importance and Application of Different Nurse Educator Competence Domains. J Nurs Educ 2002; 41(7):295-301.

30. Buchel TL and Edwards FD. Characteristics of Effective Clinical Teachers. Fam Med 2005; 37(1):30-5. 